\title{
Performance Improvement of the Parabolic Trough Solar Collector Using Different Types of Fluids with Numerical Simulation
}

Saad T. Hamidi

Electromechanical Engineering Department, University of Technology

saadtami@yahoo.com
Fikrat A.K. Fattah

\author{
Mohammed S. Ghanam
}

\begin{abstract}
Solar concentrators are an important facility to utilize the solar energy. There are many kinds of solar concentrators. In this work an experimental has been implemented to improve the thermal performance of Parabolic Trough Solar Collector (PTSC) using three different fluids as a working fluid (water, nanoparticles of $\mathrm{CuO}$ mixed with distilled water nanoparticles of $\mathrm{Al}_{2} \mathrm{O}_{3}$ mixed with distilled water) with concentration ratio $0.01 \%$ and mass flow rate $20 \mathrm{Lt} / \mathrm{hr}$ without tracking system. The experimental tests have been carried out in electro-mechanical engineering department at university of technology in Baghdad city during October 2017 and daytime between (9am -15pm) hours. The obtained results for three different fluids are as follows:
\end{abstract}

- Using $(\mathrm{CuO}+$ distilled water) as a working fluid increases the average of the output temperatures by $10.4 \%$, the average of useful heat gains increases by $11 \%$ and the average of the collector efficiencies increases by $15 \%$.

- Using $\left(\mathrm{Al}_{2} \mathrm{O}_{3}+\right.$ distilled water) as a working fluid increased the average of output temperatures by $4 \%$, the average of useful heat gains is increased by $6.5 \%$ and the average of collector efficiencies is increased by $8.2 \%$.

Key Words: Parabolic Solar collector, Nanofluid effect, Solar energy, Efficiency improvement of PTC.

\begin{tabular}{|c|c|c|}
\hline Symbols & Definition & Unit \\
\hline$A_{a}$ & Collector aperture area & $\mathrm{m}^{2}$ \\
\hline$C_{p}$ & Heat capacity & $\mathrm{J} / \mathrm{kg} . \mathrm{K}$ \\
\hline$C_{p_{f}}$ & Heat capacity of fluid & $\mathrm{J} / \mathrm{kg} . \mathrm{K}$ \\
\hline$C_{p_{n f}}$ & Heat capacity of nanofluid & $\mathrm{J} / \mathrm{kg} . \mathrm{K}$ \\
\hline$C_{p_{p}}$ & Heat capacity of nanoparticle & $\mathrm{J} / \mathrm{kg} . \mathrm{K}$ \\
\hline$I_{b}$ & Beam solar radiation & $\mathrm{W} / \mathrm{m}^{2}$ \\
\hline$K_{f}$ & Thermal conductivity of fluid & $\mathrm{W} / \mathrm{m} . \mathrm{K}$ \\
\hline$K_{n f}$ & Thermal conductivity of nanofluid & $\mathrm{W} / \mathrm{m} . \mathrm{K}$ \\
\hline
\end{tabular}




\begin{tabular}{|c|c|c|}
\hline$K_{p}$ & Thermal conductivity of nanoparticle & $\mathrm{W} / \mathrm{m} . \mathrm{K}$ \\
\hline $\mathrm{M}$ & Mass flow rate & $\mathrm{Kg} / \mathrm{hr}$ \\
\hline$m_{f}$ & Mass of fluid & $\mathrm{Kg}$ \\
\hline$m_{p}$ & Mass of nanoparticle & $\mathrm{Kg}$ \\
\hline$Q_{u, \exp }$ & Experimental useful energy & $\mathrm{W}$ \\
\hline$Q_{u, t h}$ & Theoretical useful energy & $\mathrm{W}$ \\
\hline$T_{f, i}$ & inlet fluid temperature & ${ }^{\circ} C$ \\
\hline$T_{f, o}$ & Outlet fluid temperature & ${ }^{\circ} C$ \\
\hline$V_{f}$ & Volume of fluid & $m^{3}$ \\
\hline$V_{p}$ & Volume nanoparticle & $m^{3}$ \\
\hline
\end{tabular}

\section{Greek Symbols}

\begin{tabular}{|c|c|c|}
\hline Symbols & Definition & Unit \\
\hline$\eta_{\mathrm{th}}$ & Theoretical efficiency & --------- \\
\hline$\eta_{\mathrm{ex}}$ & Experimental efficiency & ---------- \\
\hline$\varphi$ & Concentration ratio & --------- \\
\hline$\rho_{n f}$ & Density of nanofluid & $\mathrm{Kg} / \mathrm{m}^{3}$ \\
\hline$\rho_{f}$ & Density of fluid & $\mathrm{Kg} / \mathrm{m}^{3}$ \\
\hline$\rho_{p}$ & Density of nanoparticle & $\mathrm{Kg} / \mathrm{m}^{3}$ \\
\hline$\mu_{n f}$ & Viscosity of nanofluid & $\mathrm{m}^{2} / \mathrm{s}$ \\
\hline$\mu_{f}$ & Viscosity of fluid & $\mathrm{m}^{2} / \mathrm{s}$ \\
\hline
\end{tabular}

\section{Introduction}

The sun is the best energy source in this contextually and is almost a wellspring. Energy efficiency and solar technology are very important parameters to the building or community design. The radiation of the sun can be converted into other forms of energy by direct or indirect way, for example heat and electricity, which can be utilized by human. The researches and developments which started before 1970 are carried out in few countries to utilize the thermal energy in best manner, but most of these researches remained academic [1].

There are many regions and countries suitable to use the solar energy that is depending on their climate, Iraq is one of these countries because the solar rays that received with approximate time of 4000 hours per year in convenient places of solar energy [2]. The Concentrated Solar Power (CSP) is the best technology in consuming solar radiation, which bestirs the way to produce energy. Different types of CSP are used in crafting for generation of power. The Parabolic Solar Collectors (PSC) are the best technology proliferate in power plants. Efficiency of the (PSC) and heat losses during storage times are two main drags while utilizing the PSC in solar energy. Recent finds suggested that adding nano-particles to the heating fluid improve the 
thermal conductivity, thermo-physical and heat transfer properties of the fluid [3]. Nano-fluid will have a favorable effect on the performance of (PSC). [4] Described the heat transport enhancement by means of nano-powder. Altered nanofluids including $\mathrm{Al}_{2} \mathrm{O}_{3}(20 \mathrm{~nm}), \mathrm{CuO}(50 \mathrm{~nm})$, and $\mathrm{Cu}(25 \mathrm{~nm})$ nanoparticles in water were considered in their work and has been conducted in the course of laminar flow with heat transfer development through the circular tube. They specified their results to identify the improvement of heat transfer with the increase in concentration of nanoparticle. They had taken the optimum concentration value of $\mathrm{Cu}$ nanoparticles to be $2 \%$ of volume fraction and the other nanoparticles $\mathrm{Al}_{2} \mathrm{O}_{3}$ and $\mathrm{CuO}$ as $2.5 \%$ of volume fraction. The results obtained from their experimental work showed that the metallic nanoparticles had improved the heat transport coefficient as compare to that of the oxide particles. [5] Investigated theoretically thermal efficiency of a nano-fluid based direct absorbition solar parabolic trough collector, and used aluminium nanoparticles at the volume fraction of $0.05 \%$ suspended in the base fluid TherminolVP1. Their results showed that thermal efficiency increases compared to a conventional PTC by $10 \%$ at low temperatures and by 5\% at high temperatures. [6] Presented an attempt to increase the efficiency of parabolic solar collector by using copper oxide and alumina nanofluid with concentration $0.01 \%$ and the average size of nanoparticle is $20-30 \mathrm{~nm}$. The maximum instantaneous efficiency was $39.4 \%$ at flow rate $60 \mathrm{Lit} / \mathrm{hr}$ with copper oxide. [7] Studied the performance of solar nanofluid heating system using $(\mathrm{Cu}(30 \mathrm{~nm})+\mathrm{DW})$ and $\left(\mathrm{TiO}_{2}(50 \mathrm{~nm})+\mathrm{DW}\right)$ as a nanofluids. Also he used four particles concentration ratios (0,1,3 and $5 \%$ vol), mass flow rate (30, 60 and $90 \mathrm{lit} / \mathrm{hr}^{2}$ ) and the distilled water as working fluid. The efficiency of collector for nanofluid $(\mathrm{Cu}(30 \mathrm{~nm})+\mathrm{DW})$ was more than nanofluid $\left(\mathrm{TiO}_{2}(50 \mathrm{~nm})\right.$ $+\mathrm{DW})$ because the particle size of copper was small as compared with titanium oxide.

\section{Theory:}

The solar collector is formed in the shape of parabola, which is usually a mirror, or anodized Aluminum sheet depends on the applications to concentrate the radiation rays of the sun on the receiver tube that located in the focal line of the collector. The material of the absorber tube most be mild steel or copper and it is painted with black paint to improve the performance of it. The absorber tube transform the radiations into thermal energy which is carried by the working fluid that pass through the tube and use it in require application. This type of collectors can reach to $400^{\circ} \mathrm{C}$, depending upon the material that is used as a reflecting surface, absorber tube materials and heat transfer fluid. The concentrating collectors has an important factor called concentration ratio which is defined as the ratio of the aperture area of collector to the area of the absorber tube and it ranges are (20-70). 


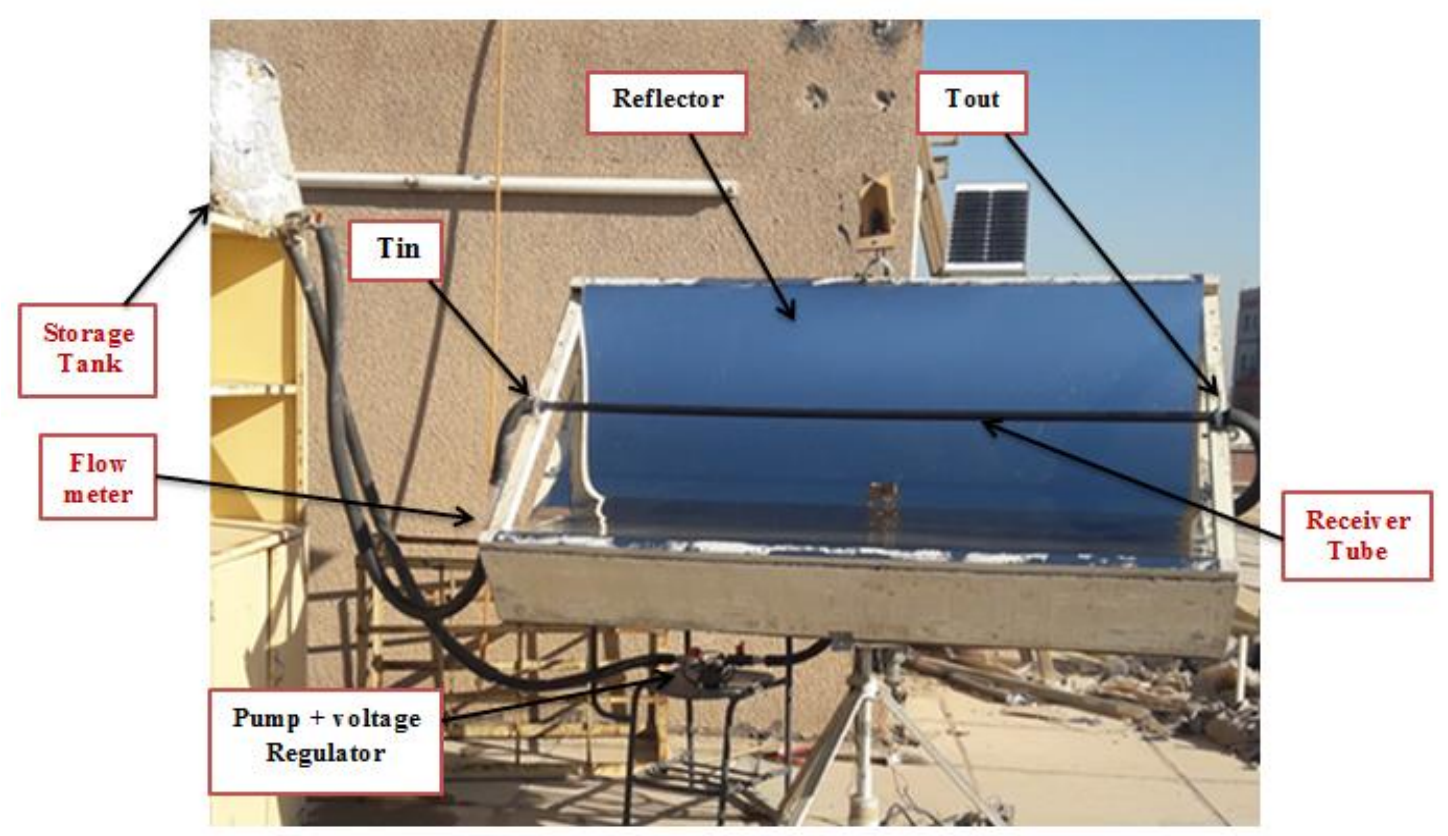

Figure (1) Parabolic Trough Solar Collector

Table (1) Specifications of Parabolic Trough Collector

\begin{tabular}{|c|c|}
\hline ITEM & Value / Type \\
\hline Collector aperture area $A_{a}$ & $1.755 \mathrm{~m}^{2}$ \\
\hline Aperture width $W_{a}$ & $1 \mathrm{~m}$ \\
\hline Length to width ratio & 1.755 \\
\hline Rim angle $\Phi_{r}$ & $90^{\circ}$ \\
\hline Tracking mechanism type & Electro-Optical \\
\hline Tracking mode & Two axis tracking \\
\hline Concentration ratio with tube CR & 35 \\
\hline
\end{tabular}

Table(2) Specifications of copper tube

\begin{tabular}{|c|c|}
\hline ITEM & Value \\
\hline Length of tube L & $1.835 \mathrm{~m}$ \\
\hline Outer diameter $D_{o}$ & $28 \mathrm{~mm}$ \\
\hline Inner diameter & $27.2 \mathrm{~mm}$ \\
\hline Thickness of tube & $0.8 \mathrm{~mm}$ \\
\hline
\end{tabular}

\section{Nano-fluid}

A nano-fluid is a fluid containing nano-meter sized particles, named nanoparticles. These fluids are engineered colloidally suspensions of nano-particles in the base fluid. The nano-particles used in nano-fluid are normally made of metals, oxides, carbides, or carbon nano-tubes. Nano particles have high thermal conductivity and convective heat transfer coefficient. Knowledge of the rheological behaviour of nanofluids is found to be very critical in deciding their suitability for convective heat transfer applications. 
Journal of University of Babylon for Engineering Sciences, Vol. (26), No. (6): 2018.

\subsection{Concentration Ratio of Nanofluid}

It presents the ratio of nanoparticles in the base fluid and it is calculated from [8]:

$\varphi=\frac{V_{n f}}{V_{n f}+p}$

Since $\rho=\frac{m}{V}$

Then $\varphi=\frac{\left({ }^{m_{p}} / v_{p}\right)}{\left({ }^{m_{p}} / \rho_{p}\right)+\left({ }^{m_{f}} / \rho_{f}\right)}$

\subsection{Nanofluid Density}

The model that is used by assuming an equipoise state between particles and fluid is obtained as follows [8]:

$\rho_{n f}=\rho_{f}(1-\varphi)-\rho_{p} \varphi$

Where,

$f=$ subscripts,

$p=$ stand for fluid and nano-particle respectively,

$\varphi=$ Concentration of nano-particles in nano-fluid.

\subsection{Nano-fluid Specific heat capacity}

The nano-fluid specific heat capacity is evaluated from equation [8]:

$C_{p_{n f}}=C_{p_{f}}(1-\varphi)-C_{p_{p}} \varphi$

\subsection{Nano-fluid viscosity.}

Different equations had been used to evaluate viscosity of nano-fluids. In this work Einstein model [9] is used:

$\mu_{n f}=\mu_{f}(1+2.5 \varphi)$

\subsection{Nano-fluids thermal-conductivity}

It is the most critical factor for analyzing heat transfer of nano-fluids. Multi models were found; in this work, Maxwell model [9] is used:

$k_{n f}=k_{f} \frac{k_{p}+2 k_{f}+2 \varphi\left(k_{p}-k_{f}\right)}{k_{p}+2 k_{f}-\varphi\left(k_{p}-k_{f}\right)}$

\section{Efficiency Evaluation:}

The actual useful energy obtained from parabolic trough solar collector is given as [10]:

$Q_{u, \exp }=M C_{P}\left(T_{f, o}-T_{f, i}\right)$ 
Journal of University of Babylon for Engineering Sciences, Vol. (26), No. (6): 2018.

The thermal theoretical efficiency is written as [10]:

$\eta_{\mathrm{th}}=\frac{\mathrm{Q}_{\mathrm{u}, \mathrm{th}}}{\mathrm{I}_{\mathrm{b}} \mathrm{A}_{\mathrm{a}}}$

The thermal experimental efficiency is written as [10]:

$\eta_{\exp }=\frac{Q_{u, e x p}}{I_{b} A_{a}}$

\section{Preparation technique of Nano-particles}

The mixing of the nanoparticles with the water is carried out in the University of Technology in the corrosion laboratory at the materials engineering department by ultrasonic cleaner device that is shown in figure (2). The particle size of $\mathrm{CuO}$ and $\mathrm{Al}_{2} \mathrm{O}_{3}$ is (30-40) $\mathrm{nm}$ and the concentration ratio is $0.01 \%$

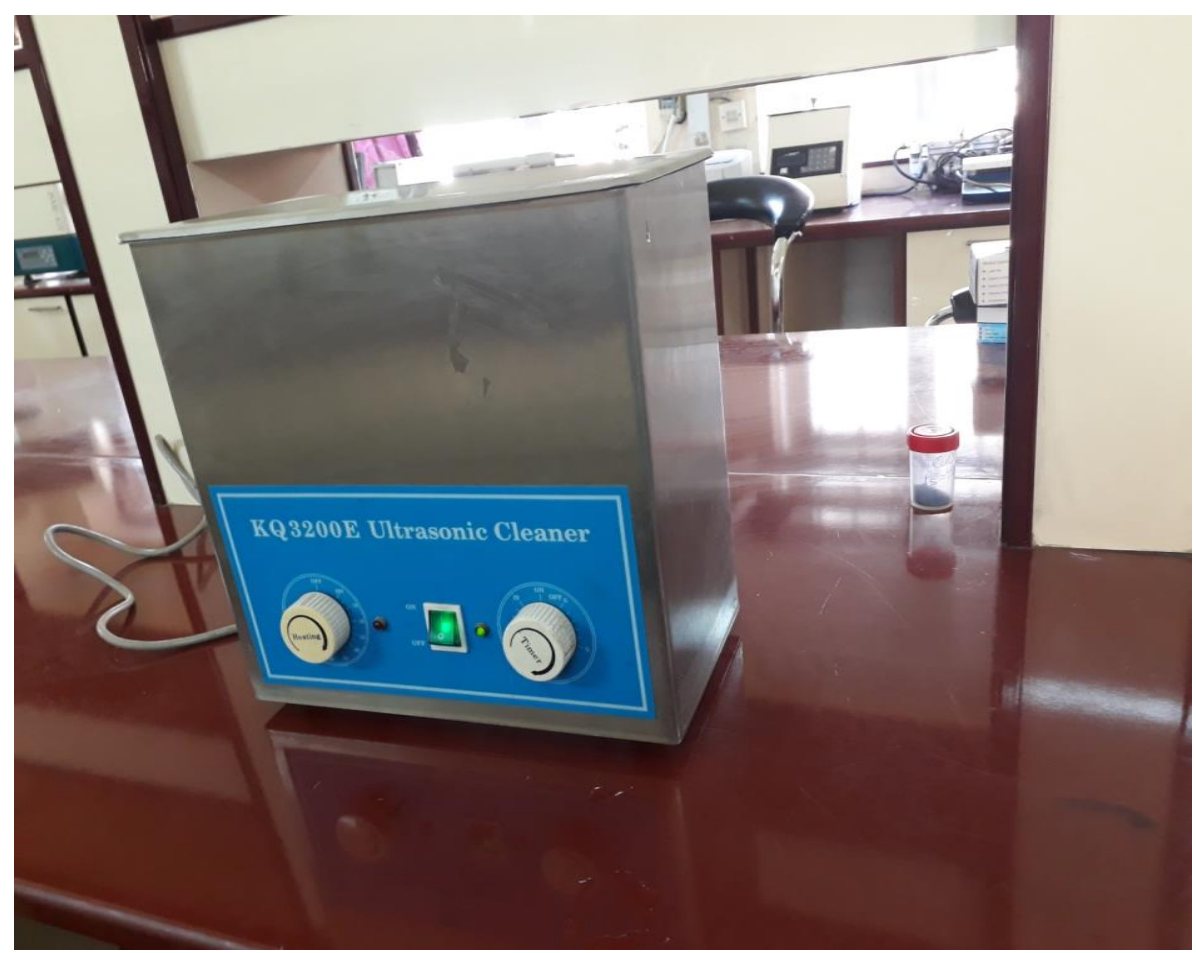

Figure (2) Ultrasonic cleaner device

Table (3) Specifications of Ultrasonic cleaner

\begin{tabular}{|c|c|}
\hline Type & KQ3200E \\
\hline Power supply & $220 \mathrm{~V}, 50 \mathrm{~Hz}$ \\
\hline Operating frequency & $40 \mathrm{KHz}$ \\
\hline Ultrasonic power & $150 \mathrm{~W}$ \\
\hline Washing volume & $6 \mathrm{~L}$ \\
\hline Adopted standards & Q/320583GSFY008-2006 \\
\hline
\end{tabular}




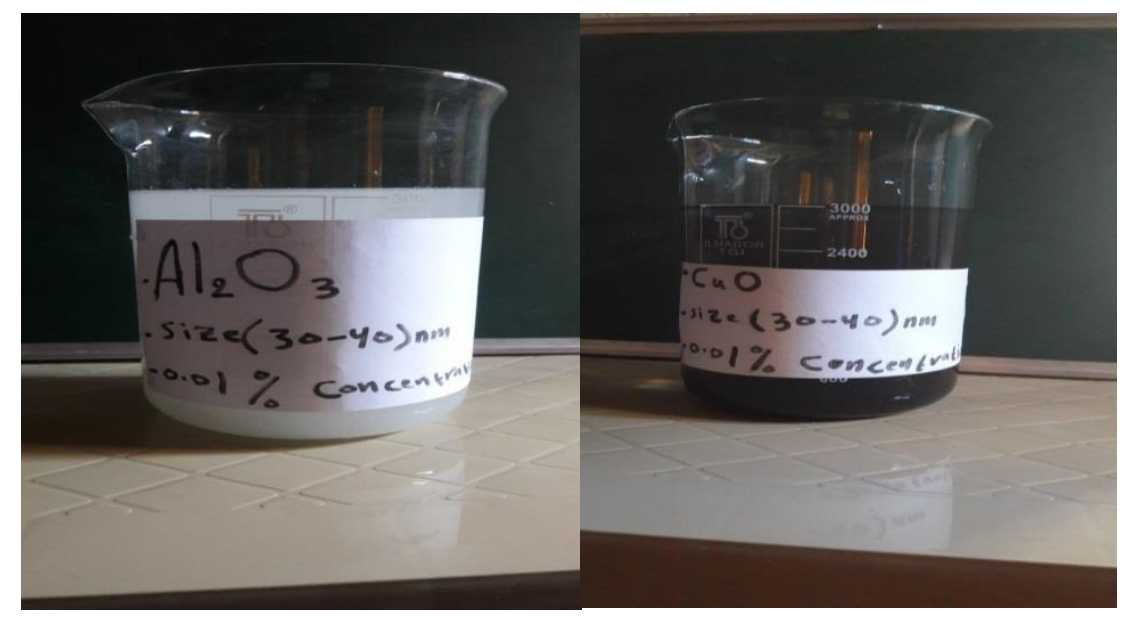

Figure (3) $\mathrm{CuO}$ and $\mathrm{Al}_{2} \mathrm{O}_{3}$ nanofluids

\section{Results and Discussion}

The results show the performance parameters of parabolic collector (output temperature, useful heat gain and efficiency).The values of solar radiation were calculated by MATLAB program .These experiments were performed in sunny days during (9 am-15 pm) of three fluids of parabolic trough solar collector.

Table (4) Results of water as a working fluid

\begin{tabular}{|c|c|c|c|c|c|c|c|c|}
\hline NO & $\begin{array}{c}\text { Time } \\
(\mathbf{h r})\end{array}$ & $\begin{array}{c}\boldsymbol{T}_{\boldsymbol{i n}} \\
\left({ }^{\circ} \mathbf{C}\right)\end{array}$ & $\begin{array}{c}\boldsymbol{T}_{\text {out }} \\
\left(^{\left.{ }^{\circ} \mathbf{C}\right)}\right.\end{array}$ & $\begin{array}{c}\boldsymbol{T}_{\boldsymbol{a m b}} \\
\left({ }^{\mathbf{o}} \mathbf{C}\right)\end{array}$ & $\begin{array}{c}\text { Wind } \\
\mathbf{m} / \mathbf{s}\end{array}$ & $\begin{array}{c}\boldsymbol{I}_{\boldsymbol{b}} \\
\left(\boldsymbol{w}_{\boldsymbol{w}} \boldsymbol{m}^{\mathbf{2}}\right)\end{array}$ & $\begin{array}{c}\boldsymbol{Q}_{\boldsymbol{u}} \\
(\mathbf{w})\end{array}$ & $\begin{array}{c}\text { Eff } \\
\boldsymbol{\%}\end{array}$ \\
\hline 1 & 9 & 20.3 & 27.2 & 27.3 & 0.34 & 385 & 161 & 23.8 \\
\hline 2 & 10 & 22 & 32.8 & 28.5 & 0.9 & 430 & 250.8 & 33.2 \\
\hline 3 & 11 & 25.1 & 41.8 & 30.1 & 1.3 & 512 & 387.7 & 43.1 \\
\hline 4 & 12 & 31 & 54 & 32.4 & 1.1 & 585 & 534 & 52 \\
\hline 5 & 13 & 38.2 & 57 & 33.9 & 1.7 & 505 & 436 & 49.3 \\
\hline 6 & 14 & 45.5 & 60 & 34.3 & 1.3 & 445 & 337 & 43.2 \\
\hline 7 & 15 & 47 & 57.3 & 34 & 2.1 & 386 & 239 & 35.2 \\
\hline
\end{tabular}

Table (5) Results of $\mathrm{CuO}$ nanofluid as a working fluid

\begin{tabular}{|c|c|c|c|c|c|c|c|c|}
\hline NO & $\begin{array}{c}\text { Time } \\
(\mathbf{h r})\end{array}$ & $\begin{array}{c}\boldsymbol{T}_{\boldsymbol{i n}} \\
\left({ }^{\mathbf{}} \mathbf{C}\right)\end{array}$ & $\begin{array}{c}\boldsymbol{T}_{\boldsymbol{o u t}} \\
\left(^{\mathbf{}} \mathbf{C}\right)\end{array}$ & $\begin{array}{c}\boldsymbol{T}_{\boldsymbol{a m b}} \\
\left({ }^{\mathbf{o}} \mathbf{C}\right)\end{array}$ & $\begin{array}{c}\text { Wind } \\
\mathbf{m} / \mathbf{s}\end{array}$ & $\begin{array}{c}\boldsymbol{I}_{\boldsymbol{b}} \\
\left(\mathbf{w}_{\mathbf{m}} \mathbf{2}\right)\end{array}$ & $\begin{array}{c}\boldsymbol{Q}_{\boldsymbol{u}} \\
(\mathbf{w})\end{array}$ & Eff \% \\
\hline 1 & 9 & 17.1 & 24.5 & 24 & 3.4 & 326 & 163.5 & 28.5 \\
\hline 2 & 10 & 21 & 32.7 & 24.8 & 3.5 & 416 & 257 & 37.4 \\
\hline 3 & 11 & 27 & 48.1 & 26 & 3.1 & 518 & 464.3 & 51 \\
\hline 4 & 12 & 34.1 & 60 & 27.4 & 3 & 526 & 570 & 61.7 \\
\hline 5 & 13 & 42.5 & 66 & 28.3 & 2.7 & 520 & 539 & 59 \\
\hline 6 & 14 & 49.2 & 68 & 29.1 & 2.5 & 460 & 371 & 46 \\
\hline 7 & 15 & 52.3 & 63 & 29.5 & 2.7 & 343 & 235.4 & 39.8 \\
\hline
\end{tabular}


Journal of University of Babylon for Engineering Sciences, Vol. (26), No. (6): 2018.

Table (6) Results of $\mathrm{Al}_{2} \mathrm{O}_{3}$ nanofluid as a working fluid

\begin{tabular}{|c|c|c|c|c|c|c|c|c|}
\hline NO & $\begin{array}{c}\text { Time } \\
(\mathbf{h r})\end{array}$ & $\begin{array}{c}\boldsymbol{T}_{\boldsymbol{i n}} \\
\left({ }^{\mathbf{o}} \mathbf{C}\right)\end{array}$ & $\begin{array}{c}\boldsymbol{T}_{\boldsymbol{o u t}} \\
\left({ }^{\circ} \mathbf{C}\right)\end{array}$ & $\begin{array}{c}\boldsymbol{T}_{\boldsymbol{a m b}} \\
\left({ }^{\mathbf{o}} \mathbf{C}\right)\end{array}$ & $\begin{array}{c}\text { Wind } \\
\mathbf{m} / \mathbf{s}\end{array}$ & $\begin{array}{c}\boldsymbol{I}_{\boldsymbol{b}} \\
\left(\boldsymbol{w} / \boldsymbol{m}^{\mathbf{2}}\right)\end{array}$ & $\begin{array}{c}\boldsymbol{Q}_{\boldsymbol{u}} \\
(\mathbf{w})\end{array}$ & $\begin{array}{c}\text { Eff } \\
\boldsymbol{\%}\end{array}$ \\
\hline 1 & 9 & 17.4 & 23.8 & 19.2 & 0.44 & 312 & 141 & 25.3 \\
\hline 2 & 10 & 20 & 30.9 & 20 & 0.97 & 402 & 245 & 34.7 \\
\hline 3 & 11 & 26.7 & 45.6 & 21.3 & 1.1 & 525 & 422.3 & 45.8 \\
\hline 4 & 12 & 33.2 & 58 & 22.6 & 1.6 & 552 & 553 & 57 \\
\hline 5 & 13 & 39 & 62.5 & 24 & 1.7 & 541 & 524 & 55.1 \\
\hline 6 & 14 & 45.3 & 62 & 24.8 & 0.82 & 439 & 373 & 48.4 \\
\hline 7 & 15 & 49.5 & 60 & 25.3 & 1.5 & 368 & 235.2 & 36.5 \\
\hline
\end{tabular}

\subsection{Temperature versus time}

There is a gradual increasing of output temperature of the working fluid as a result of beam solar radiation increasing. The averages values of outlet temperatures are $(47.1,52,49){ }^{\circ} \mathrm{C}$ for water, water based $\mathrm{CuO}$ and water based $\mathrm{Al}_{2} \mathrm{O}_{3}$ respectively. We note that the outlet temperature using water based $\mathrm{CuO}$ as a working fluid is more than the water and water based $\mathrm{Al}_{2} \mathrm{O}_{3}$ by $(10.4,6.1) \%$ respectively.

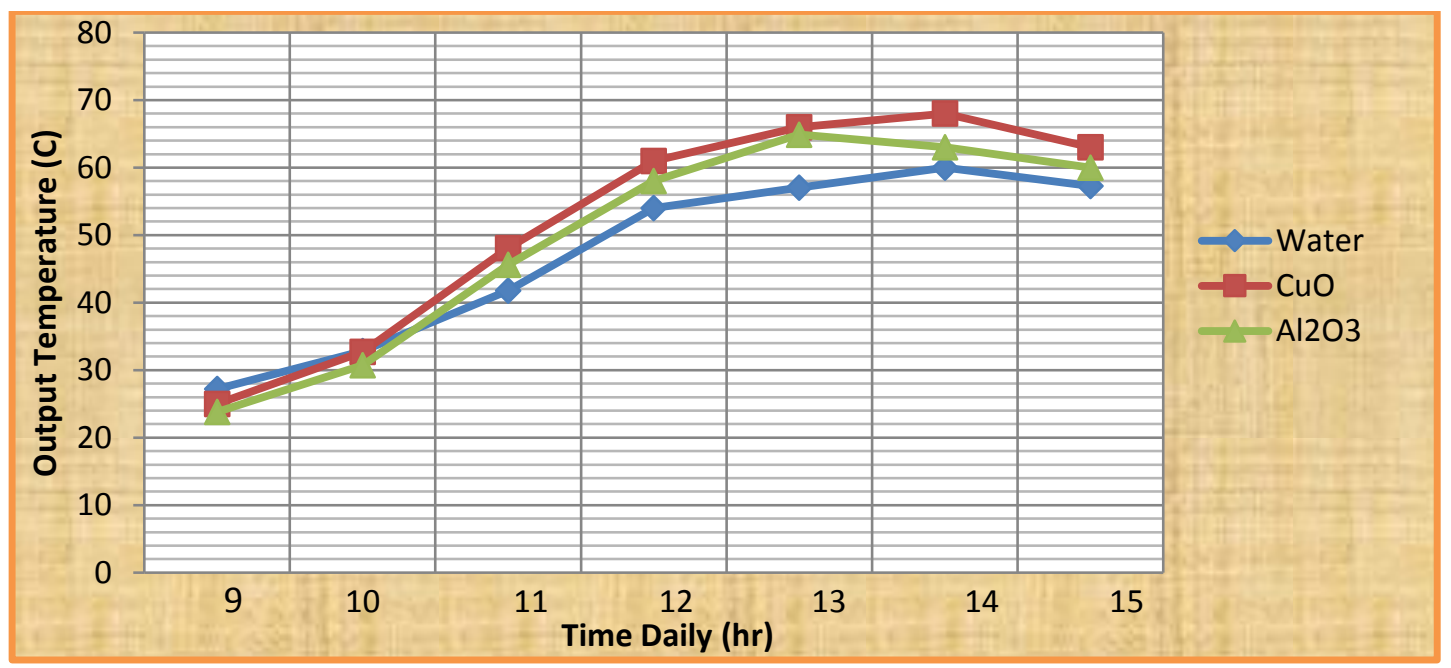

Figure (4) Output temperature versus time

\subsection{Heat gain versus time}

There is a gradual increasing in useful heating gain because of solar radiation increasing. The averages values of useful heat gains from the solar collector are (335, $372,357)$ watt for water, water based $\mathrm{CuO}$ and water based $\mathrm{Al}_{2} \mathrm{O}_{3}$ respectively. We note that the useful heat gain using water based $\mathrm{CuO}$ as a working fluid is more than the water and water based $\mathrm{Al}_{2} \mathrm{O}_{3}$ by $(11,4.2) \%$ respectively. 
Journal of University of Babylon for Engineering Sciences, Vol. (26), No. (6): 2018.

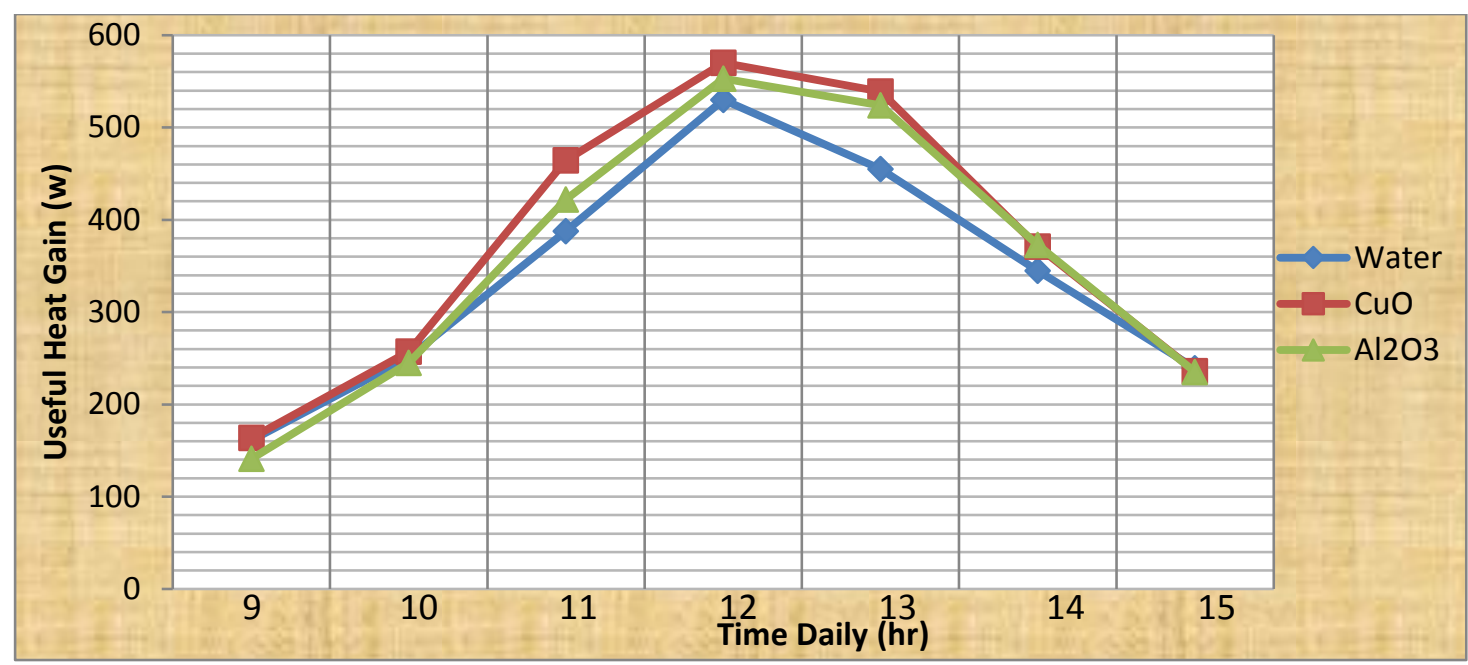

Figure (5) Useful heat gain versus time

\subsection{Efficiency versus time}

There is a gradual increasing in the efficiency of the solar collector as a result of solar radiation increasing. The averages values of efficiencies from the solar collector are $40 \%, 46.2 \%$ and 43.3 for water, water based $\mathrm{CuO}$ and water based $\mathrm{Al}_{2} \mathrm{O}_{3}$ respectively. We note that the efficiency of the solar collector when used water based $\mathrm{CuO}$ as a working fluid is more than the water and water based $\mathrm{Al}_{2} \mathrm{O}_{3}$ by $(15.5,6.7)$ $\%$ respectively.

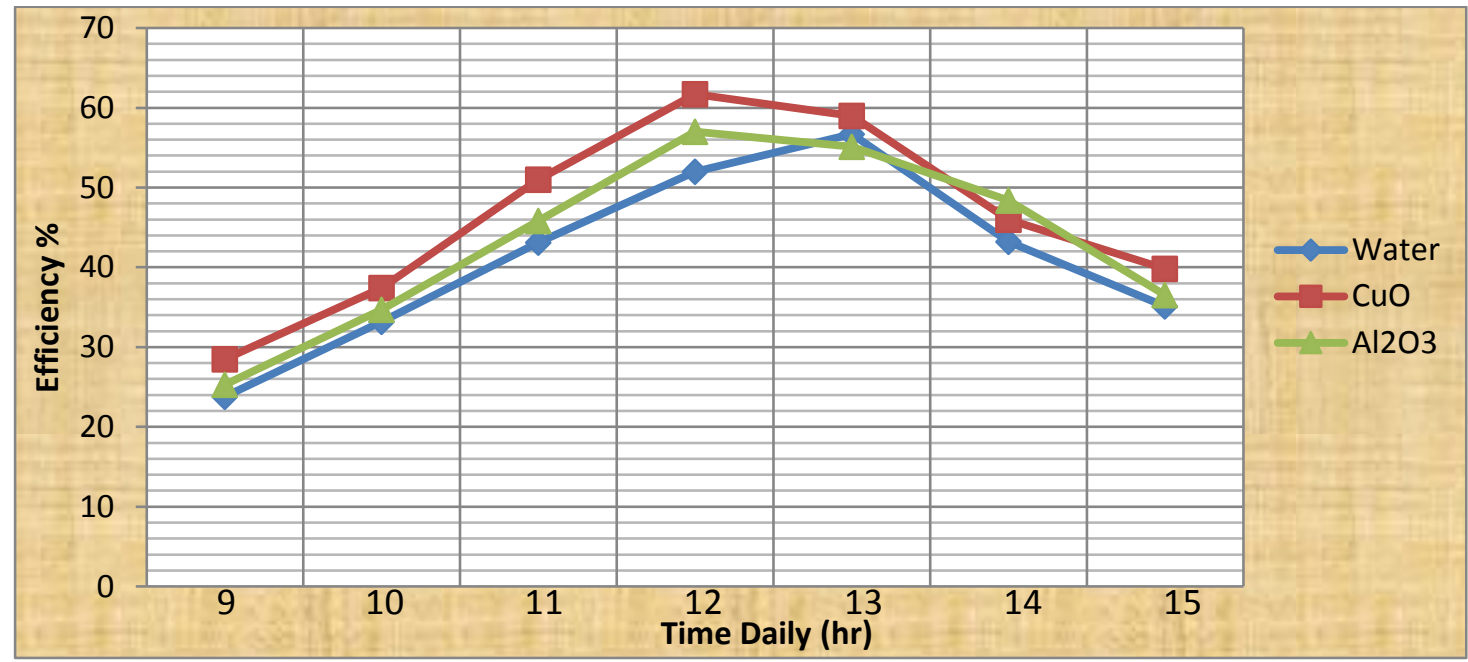

Figure (6) Efficiency versus time

\subsection{Comparative between experimental and numerical results}

The numerical simulation was taken for four hours only (9am, 11am, 13pm and $15 \mathrm{pm})$, therefore it is results should be compared with the same flow rate and time. There are differences between experimental and numerical results.

The average of numerical output temperature is more than the experimental by $(9.6,12.1,11) \%$ for water, water based $\mathrm{CuO}$ and water based $\mathrm{Al}_{2} \mathrm{O}_{3}$ respectively. 
Journal of University of Babylon for Engineering Sciences, Vol. (26), No. (6): 2018.

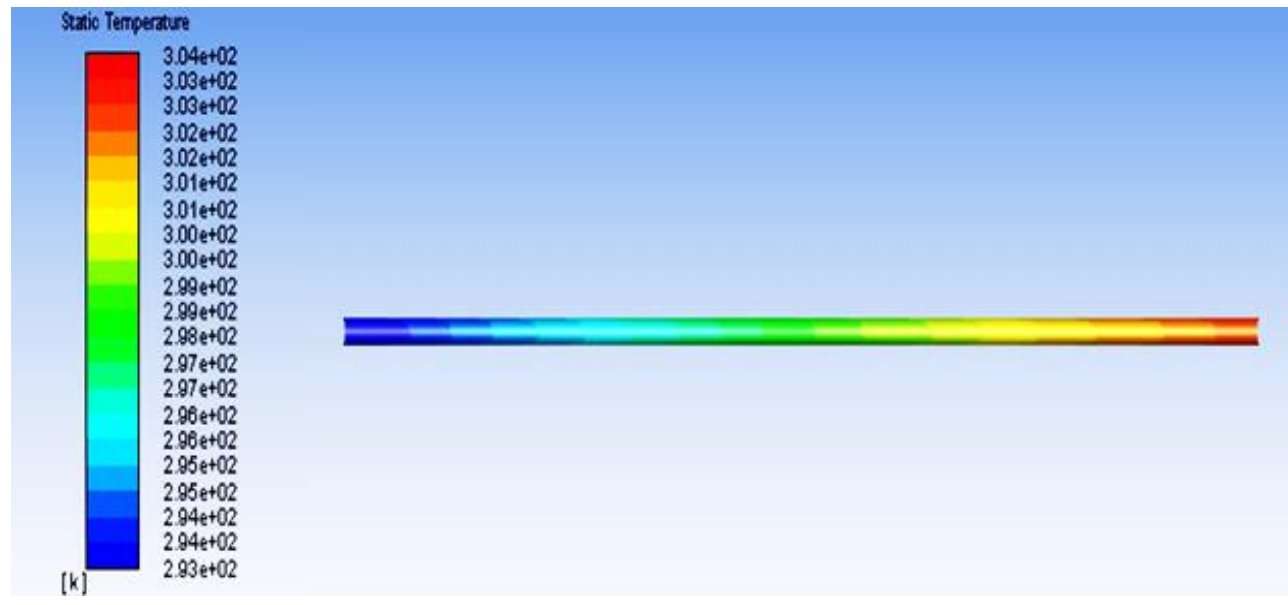

Figure (7) Temperature of water at 9 am

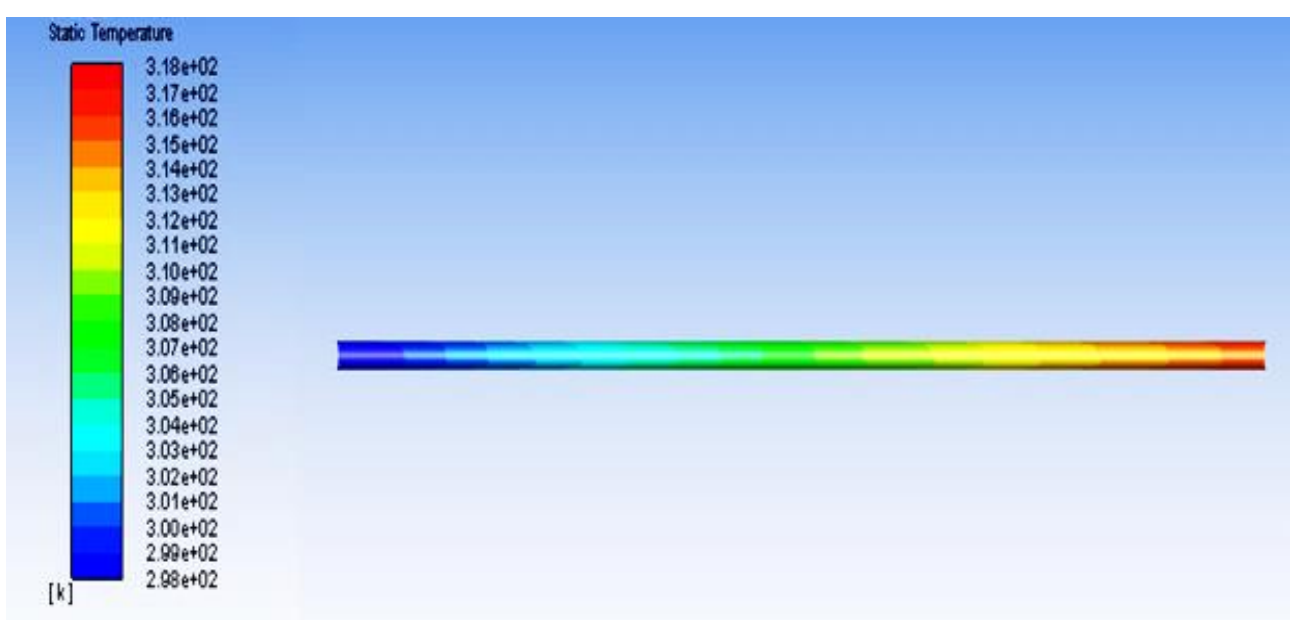

Figure (8) Temperature of water at 11 am

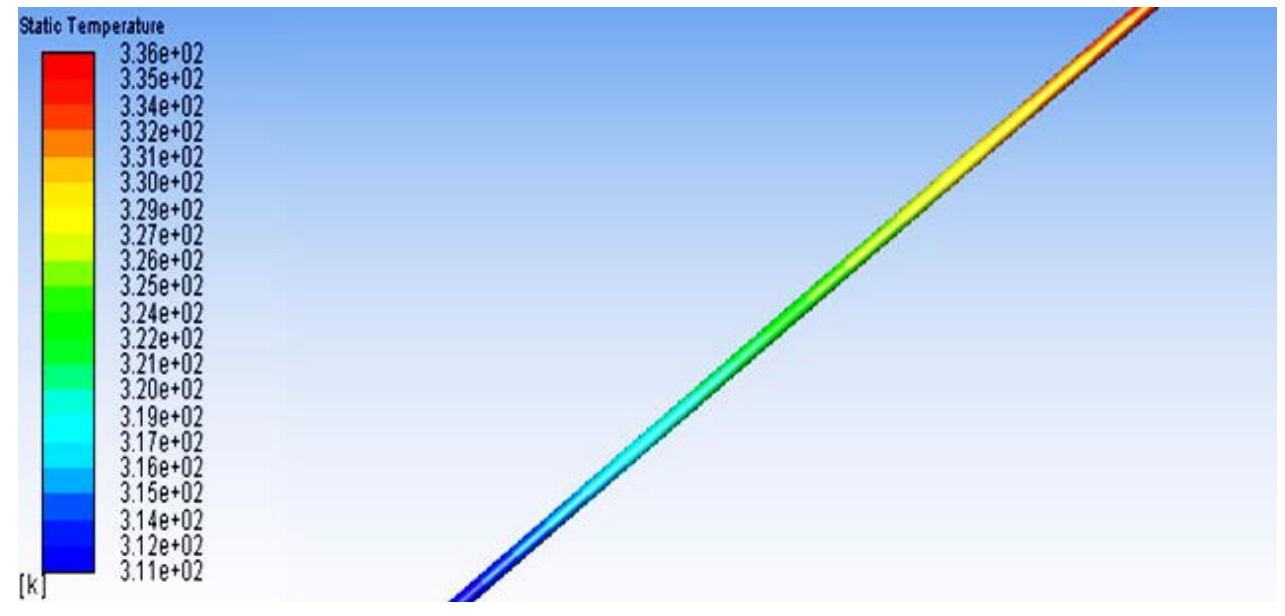

Figure (9) Temperature of water at 13 am 
Journal of University of Babylon for Engineering Sciences, Vol. (26), No. (6): 2018.

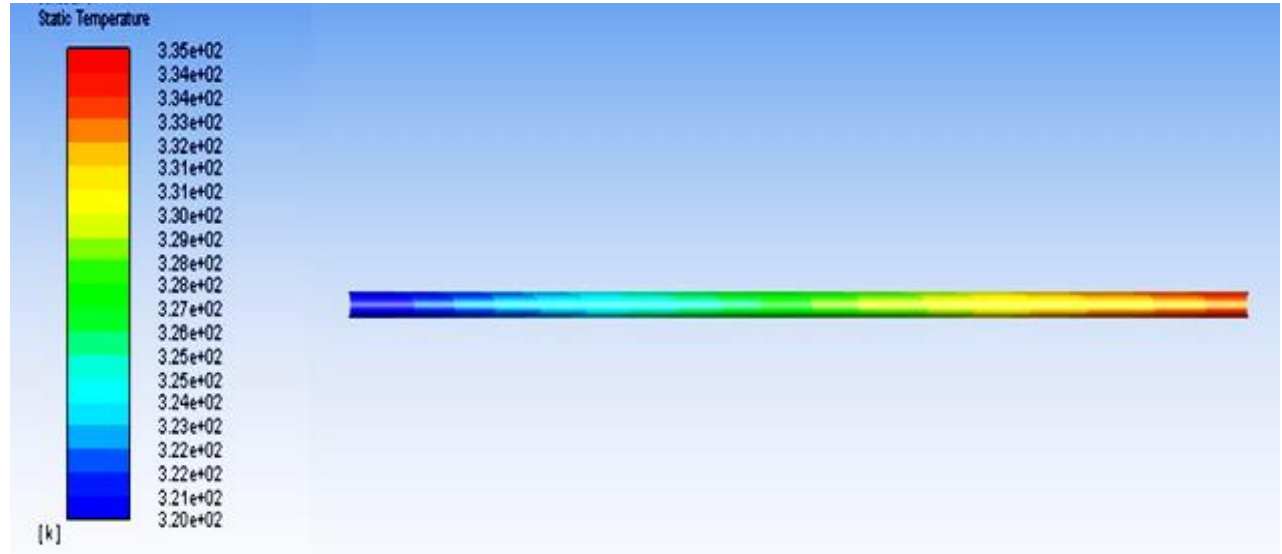

Figure (10) Temperature of water at $15 \mathrm{pm}$

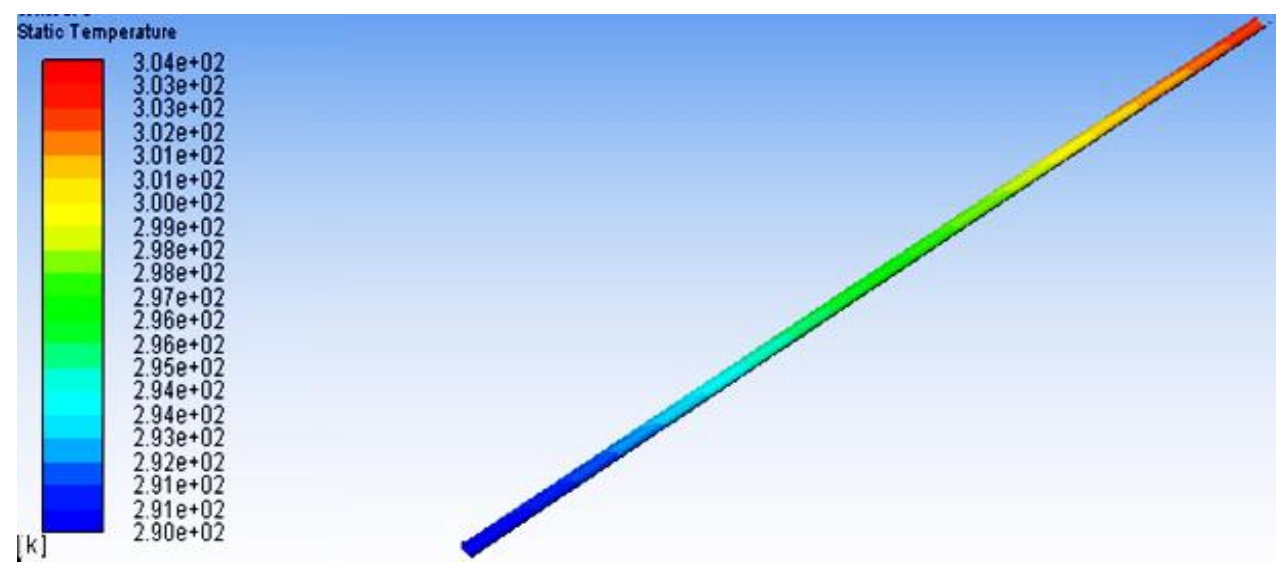

Figure (11) Temperature of water based $\mathrm{CuO}$ at $9 \mathrm{am}$

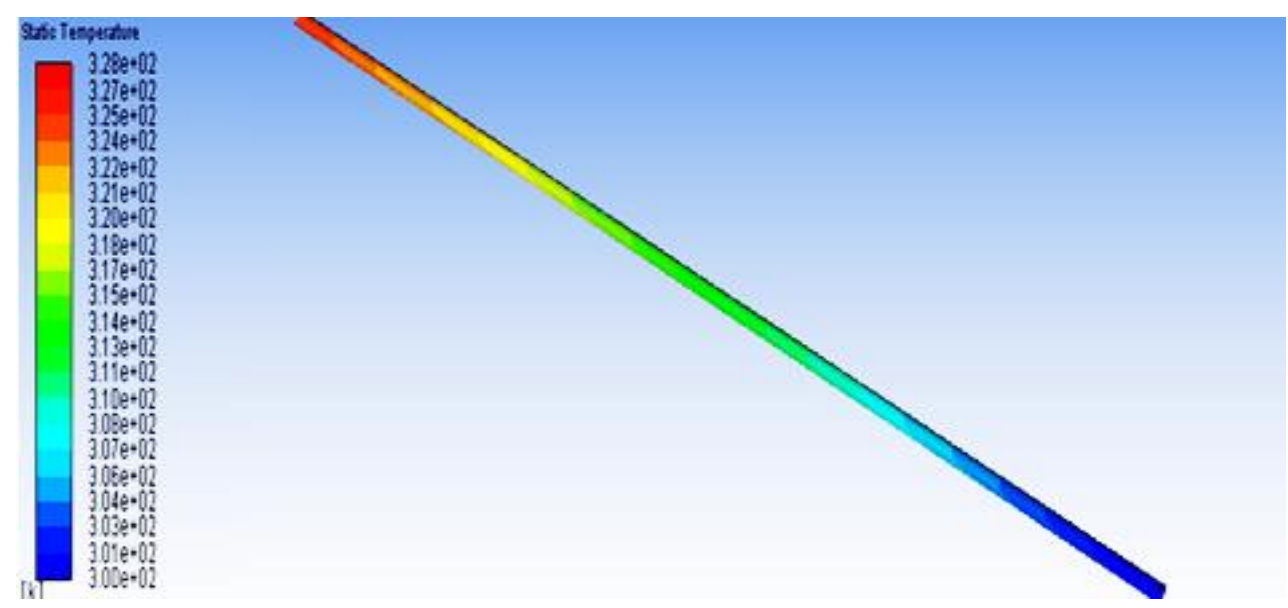

Figure (12) Temperature of water based $\mathrm{CuO}$ at $11 \mathrm{am}$ 
Journal of University of Babylon for Engineering Sciences, Vol. (26), No. (6): 2018.

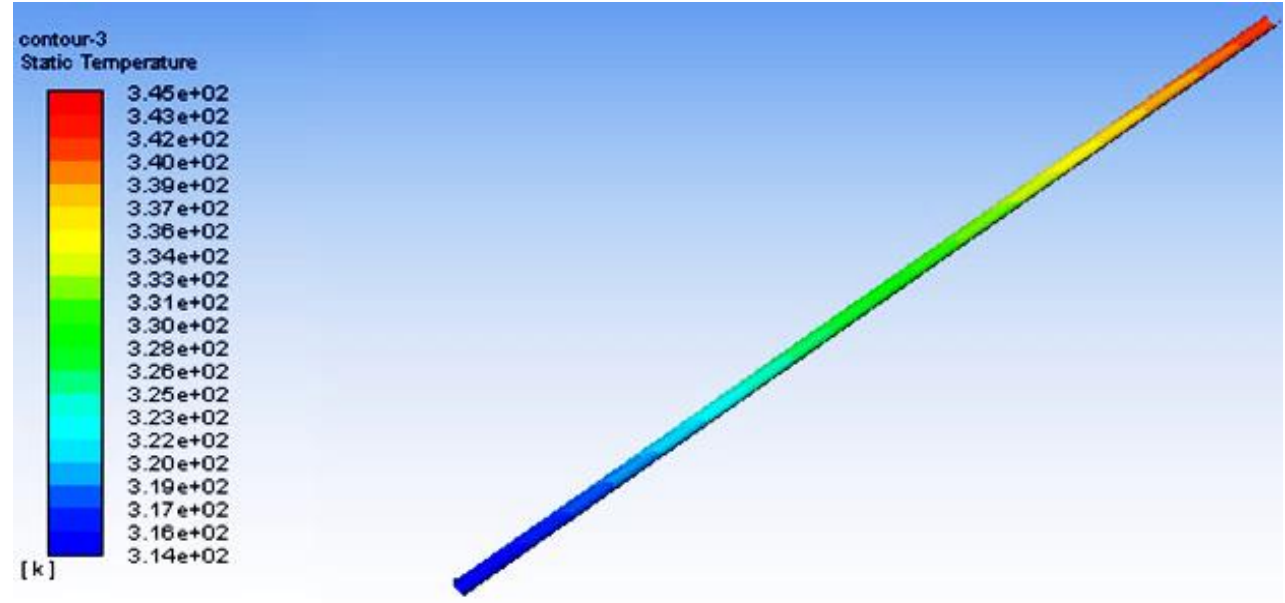

Figure (13) Temperature of water based $\mathrm{CuO}$ at $13 \mathrm{pm}$

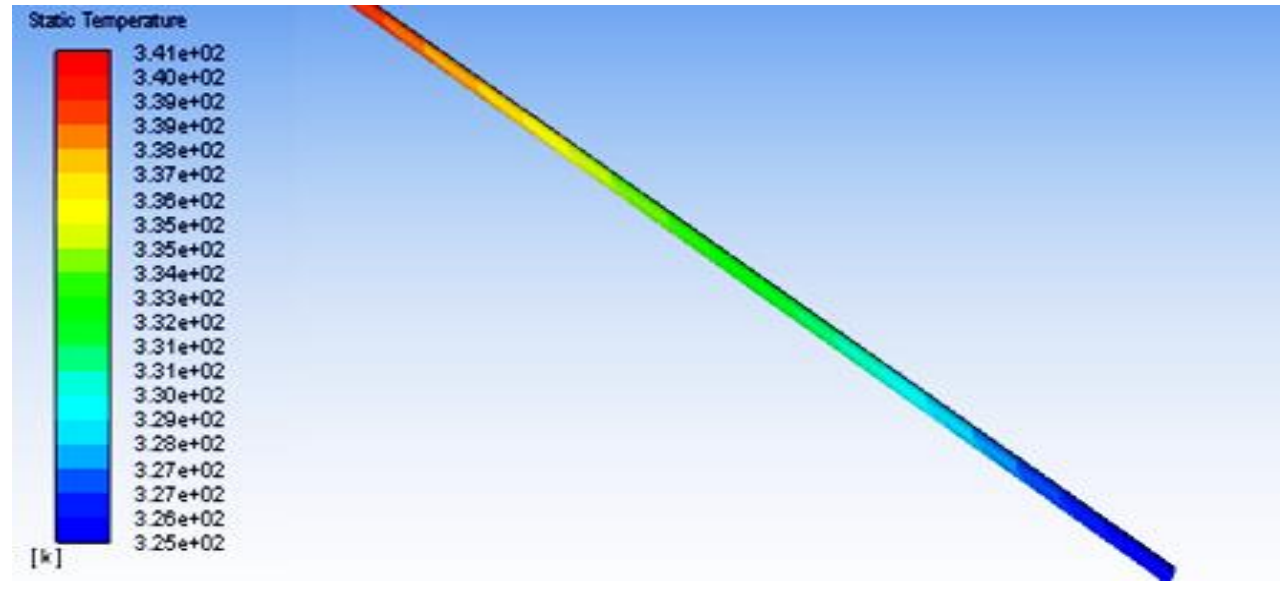

Figure (14) Temperature of water based $\mathrm{CuO}$ at $15 \mathrm{pm}$

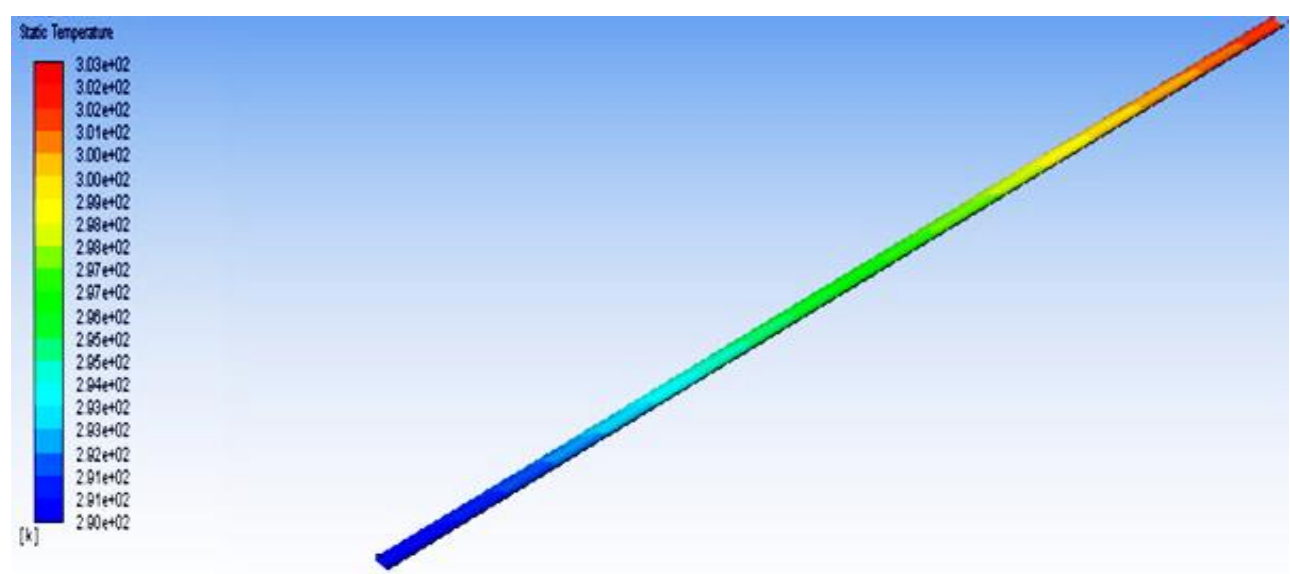

Figure (15) Temperature of water based $\mathrm{Al}_{2} \mathrm{O}_{3}$ at 9am 
Journal of University of Babylon for Engineering Sciences, Vol. (26), No. (6): 2018.

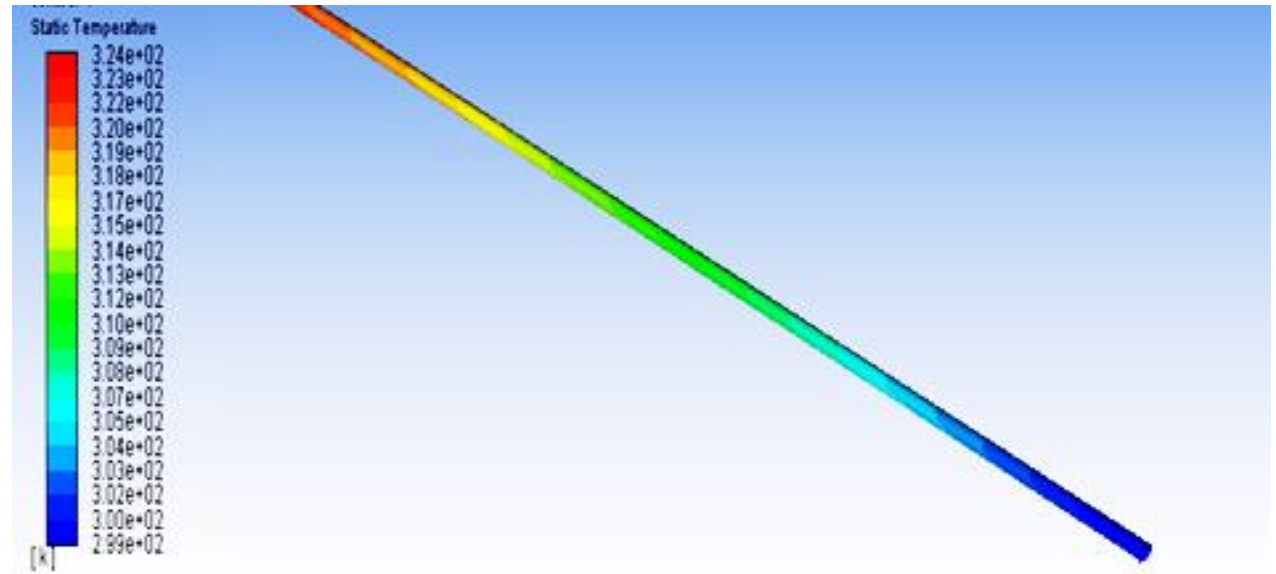

Figure (16) Temperature of water based $\mathrm{Al}_{2} \mathrm{O}_{3}$ at 11am

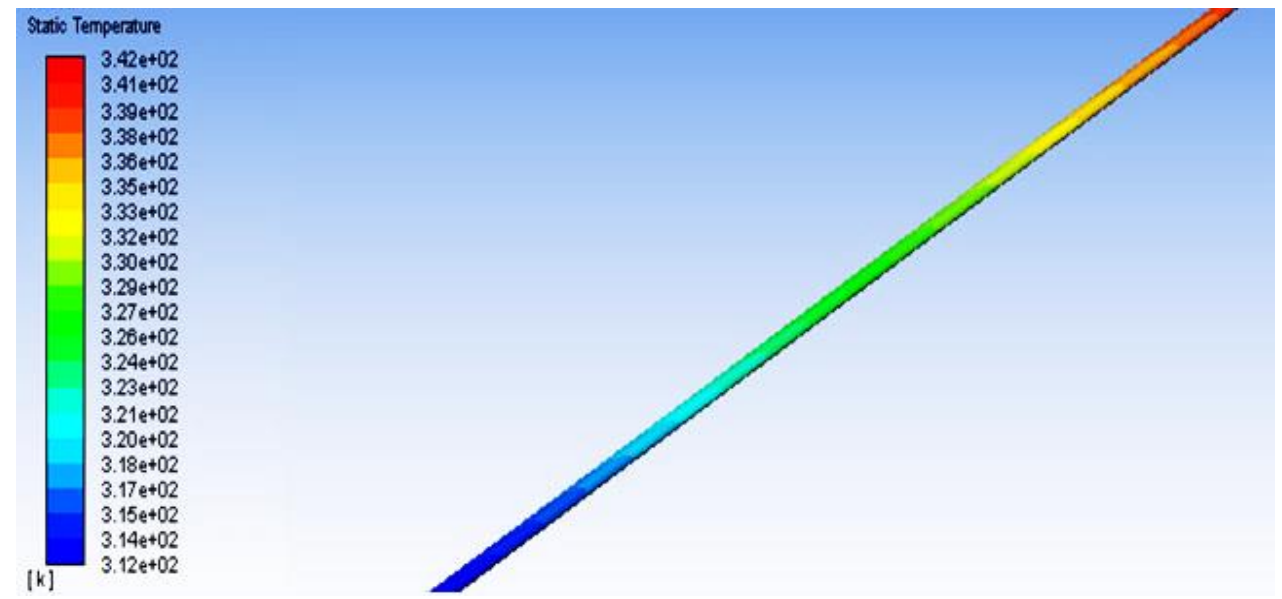

Figure (17) Temperature of water based $\mathrm{Al}_{2} \mathrm{O}_{3}$ at $13 \mathrm{pm}$

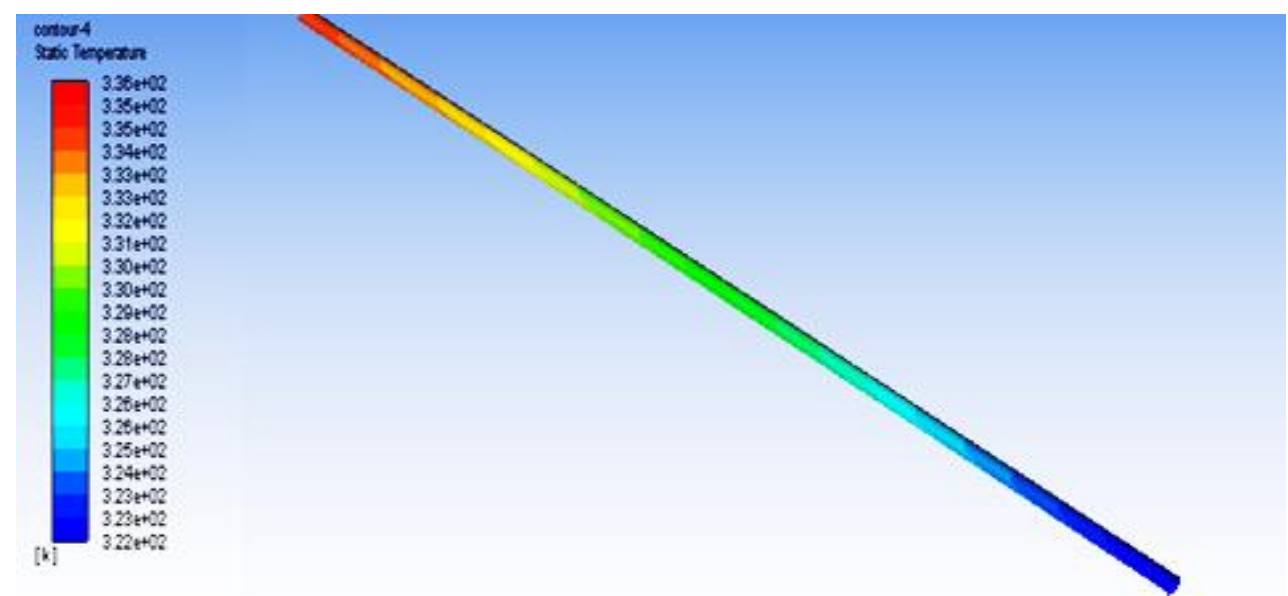

Figure (18) Temperature of water based $\mathrm{Al}_{2} \mathrm{O}_{3}$ at $15 \mathrm{pm}$ 
Journal of University of Babylon for Engineering Sciences, Vol. (26), No. (6): 2018.

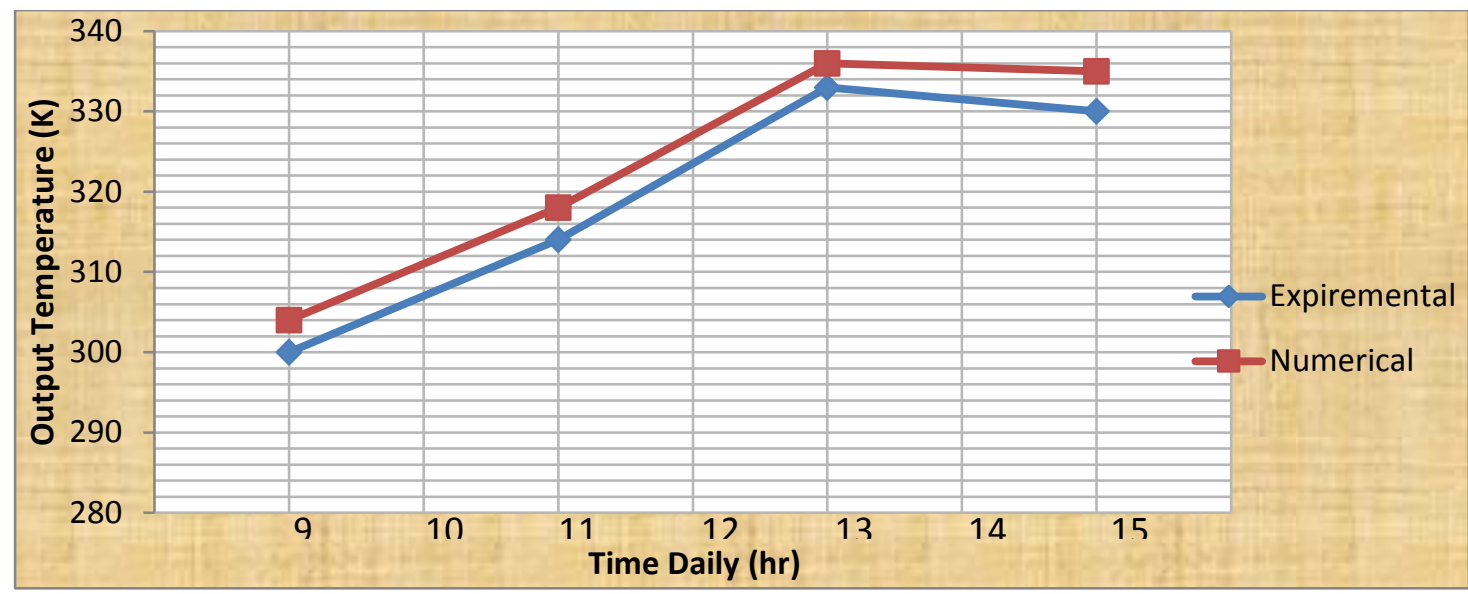

Figure (19) Difference between Experimental and Numerical output temperature for water

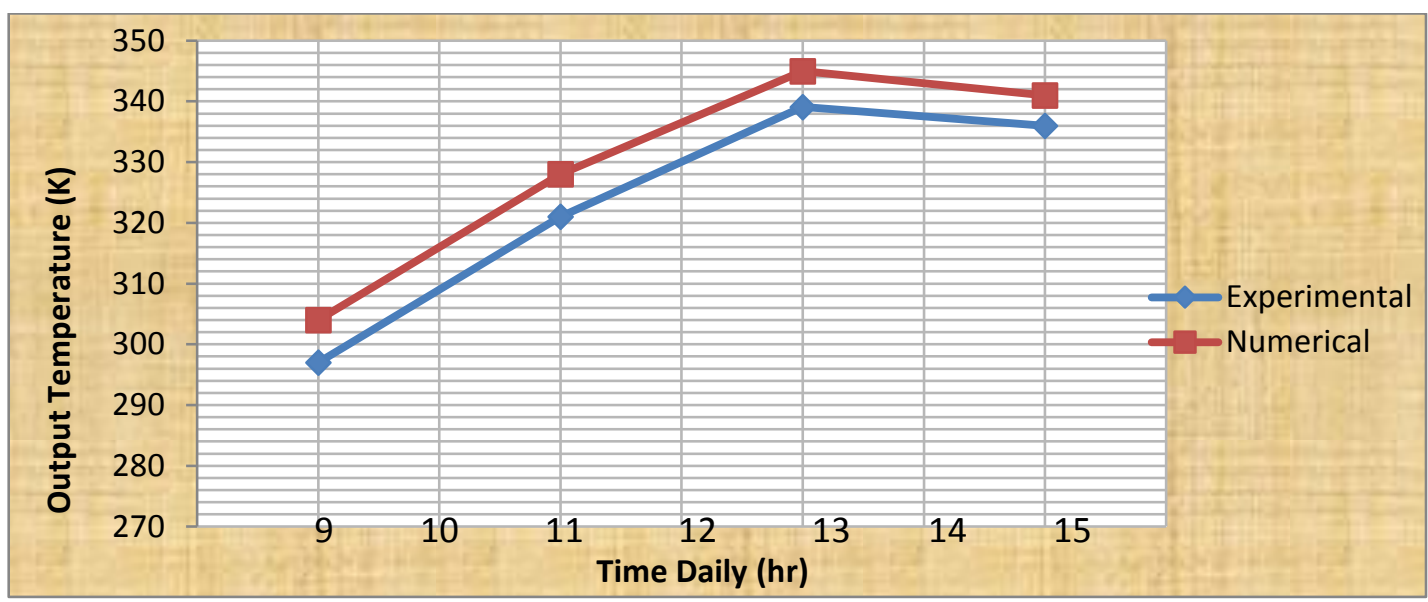

Figure (20) Difference between Experimental and Numerical output temperature for water based $\mathrm{CuO}$

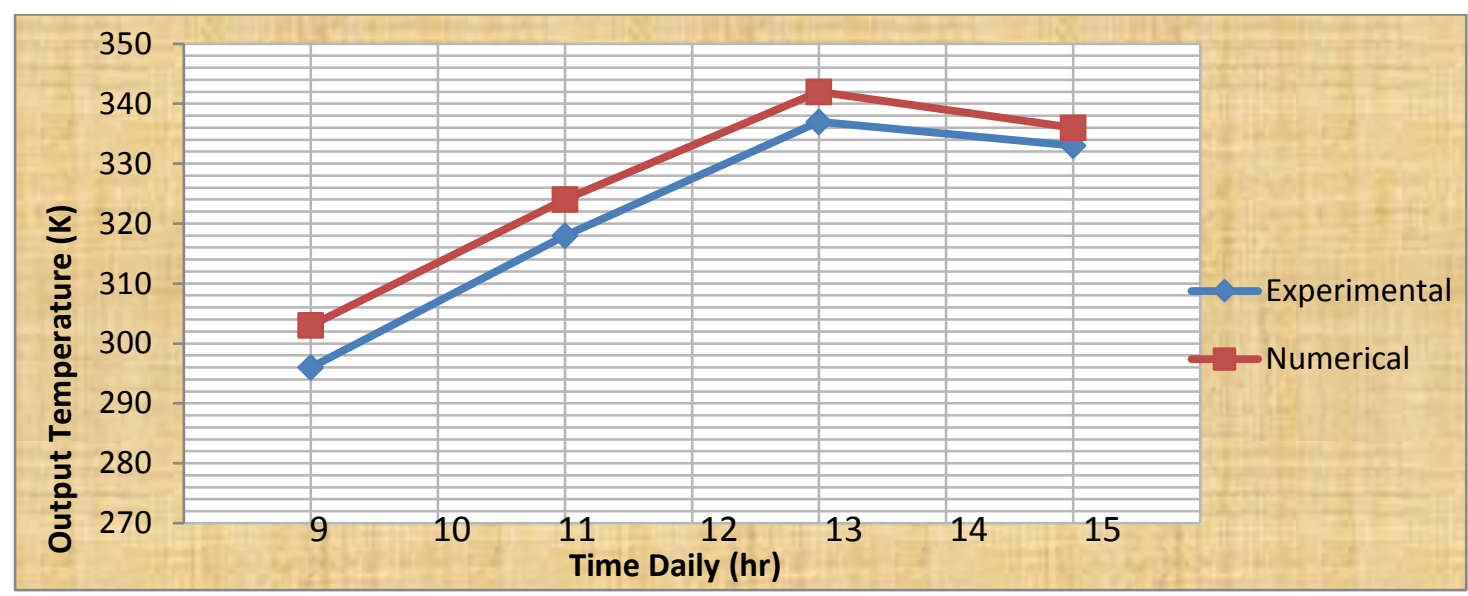

Figure (21) Difference between Experimental and Numerical output temperature for water based $\mathrm{Al}_{2} \mathrm{O}_{3}$ 
Journal of University of Babylon for Engineering Sciences, Vol. (26), No. (6): 2018.

\section{Conclusion}

The main goal of this work is to improve the performance of the Parabolic Trough Solar Collector by using water, distilled water based copper oxide $\mathrm{CuO}$ and distilled water based Aluminum oxide $\mathrm{Al}_{2} \mathrm{O}_{3}$ with concentration ratio $0.01 \%$ and with mass flow rate $20 \mathrm{Lt} / \mathrm{hr}$ without tracking system. The experimental results are shows that:

1- By using water based $\mathrm{CuO}$ as a working fluid and compare the results with results of water:

The output temperature is improved by $10.4 \%$, useful heat gain is improved by $11 \%$ and the collector efficiency is improved by $15.5 \%$.

2- By using water based $\mathrm{Al}_{2} \mathrm{O}_{3}$ as a working fluid and compare the results with results of water:

The output temperature is improved by $4 \%$, useful heat gain is improved by $6.5 \%$ and the collector efficiency is improved by $8.2 \%$.

\section{References}

[1] Bhargva. M, "Modeling, analysis, evaluation, selection and experimental investigation collector system of parabolic trough solar" Master thesis, Thermal Engineering, 2012.

[2] Donald. R, "Solar Energy", Prentice-Hall, Englewood Cliffs, NJ, 1981.

[3] Alashkar. A "Evaluation of an integrated PTSC/ Thermal energy storage system using nano-fluid particles" College of Engineering in Partial Fulfillment of the Requirements for the Degree of Master of Science in Mechanical Engineering, 2016.

[4] Hamed Mosavian.M. T, Heris. S. Z, Etemad. S. G and Esfahany. M. N, "Heat transfer enhancement by application of nanopowder", "Journal of Nanoparticle Research", Vol. 12, No 7, pp 2611-2619, 2010.

[5] Khullar. V, Tyagi. H, Phelan. P. E, Otanicar. T. P, Singh. H, Taylor. R. A, "Solar energy harvesting using nanofluids-based concentrating solar collector", Nanotechnology Eng Med, vol. 3, 2012.

[6] Sharma. K and Kundan. L, "Nanofluid Based Concentrating Parabolic Solar Collector (NBCPSC)", IJRMET Vol. 4, 2014.

[7] Sultan. K. F, "Experimental evaluation of the thermal performance in the solar nanofluid heating system by using copper and titanium oxide" The Iraqi Journal for Mechanical and Material Engineering, Vol.15, No4, 2015.

[8] Einstein. A, "Eineneue Bestimmung der Moleküldimensionen" , Ann. Phys., vol. 324, no. 2, pp. 289-306, 1906.

[9] Maxwell. J, "An Elementary Treatise on Electricity", Science, vol. 3, No. 80, 1882.

[10] Duffie. J.Aand Beckman. A,"Solar Engineering of Thermal Processes", John Wiley \& Sons Inc, 2nd Edition, 1991. 
Journal of University of Babylon for Engineering Sciences, Vol. (26), No. (6): 2018.

$$
\text { محمد سلام غنام }
$$

saadtami@yahoo.com_fikrat60@yahoo.com_mohammedsalam628000@gmail.com

\section{الخلاصة}

المركزات الثمسية وسيلة مهمة لأستخدام طاقة الثمس. هنالك عدة انواع من المركزات الثمسية. في العمل الحالي محاولة تجريبية لتحسين الاداء الحراري للجامع الثمسي ذو القطع المكافىء بأستخدام ثلاثة موائع مختلفة (ماء، ماء مقطر مع جزيئات اوكسيد النحاس النانوية، ماء مقطر مع جزيئات الالومينا النانوية) مع نسبة تركيز 0.01 \%، وسرعة جريان 20 لتز ساعة، وبدون استخدام نظام التتبع مع محاكاة رقمية. الاختبار التجريبي تم في مدينة بغداد في قسم الهندسة الكهروميكانيكية في الجامعة التكنولوجية خلال ايام شهر تثرين الاول 2017 خلال وقت النهار (9 صباحا - 15 مساءا). النتائج المحسوبة للمو ائع الثلاثة كما يلي: - استخدام (CuO) + ماء مقطر) يزيد معدل درجات الحرارة الخارجة بنسبة 10.4\% ومعدل المكاسب الحرارية زاد بنسبة 11\% ومعدل الكفاءات ز اد بنسبة 15.5\%. - استخدام ( الحرارية زاد بنسبة 6.5 \% ومعدل الكفاءات زاد بنسبة 8.2\%. هذه النتائج تبين نلك، استخدام المائع (ماء مقطر + CuO ) بعطي أفضل اداء بالمقارنة مع المائعين الاخرين المستخدمين في هذا العمل. الكلمات المفتاحية: الجامع الثمسي ذو القطع المكافى، تأثير النانو فلود، الطاقة الثمسية، تحسين كفاءة الجامع الثمسي المقعر ذو القطع المكافىء. 